赤血球前駆細胞に対する選択的培養法を用いた赤血球の

\author{
分化と $\mathrm{A}$ 执よび $\mathrm{B}$ 抗原の発現について \\ 津本 順史 ${ }^{1)}$ 梶井 英治 ${ }^{1)}$ 小幡 隆 ${ }^{2)}$ \\ 雨宮 洋一2) 須田 年生 ${ }^{3)}$ 池本 卯典 ${ }^{1)}$ \\ ${ }^{1)}$ 自治医科大学法医学 - 人類遺伝学, ${ }^{2)}$ 同 輸血部, \\ 3)熊本大学医学部附属遺伝発生医学研究施設分化制御部門
}

(平成 5 年 3 月 4 日受付)

\title{
THE MECHANISM OF EXPRESSION OF A AND B ANTIGENS ON ERYTHROID CELLS CULTURED BY A TWO PHASE LIQUID CULTURE SYSTEM
}

\author{
J. Tsumoto'), E. Kajiii"), T. Obata ${ }^{2)}$, Y. Amemiya ${ }^{2)}$, T. Suda ${ }^{3)}$ and S. Ikemoto') \\ Department of Legal Medicine and Human Genetics ${ }^{11}$ and Division of Blood Transfusion ${ }^{2)}$, Jichi Medical School and \\ Department of Cell Differentiation, Institute of Molecular Embryology and Genetics; \\ Kumamoto University School of Medicine ${ }^{3)}$
}

In order to examine productions of $A$ and their reactivites, we applied a selective two phase liquid culture system for human erythroid progenitors. The erythroid progenitors were prepared from peripheral blood of three healthy volunteers with blood group $A, B$ and $O$ in the $A B O$ blood group system. The cultured cells were analyzed with flow cytometry employing monoclonal anti-A, anti-B and anti-A + B antibodies. On day 11 of the second phase, the A and B antigens were detected on $72.1 \%$ and $49.9 \%$ of the cultured cells from blood group antigen of $A$ and $B$, respectively. When two of erythroid progenitors from three volunteers were co-cultured, no transformation of phenotype in the $\mathrm{ABO}$ blood system was observed. This result suggested that the A and B transferases only affected the erythroid cultured cells which produced them.

\section{序言}

赤血球膜の遺伝標識 $\mathrm{ABO}$ システムは, 1900年 Landsteinerによって発見され以来多くの研究者 によって，その亜型や変異型の存在も明らかにさ

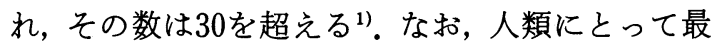
も重要な $\mathrm{ABO}$ システムは輸血学や人類遺伝学, 法医学などの分野に数多くの重要な知見を提供し てきた。また，その血液型を決定する A 型および $\mathrm{B}$ 型抗原決定基としての糖鎖構造も明らかとなっ た ${ }^{2)}$.その $\mathrm{A}$ 型および $\mathrm{B}$ 型抗原物質は $\mathrm{A}$ および $\mathrm{B}$ 転移酵素の作用によって生合成される二次的な遺 伝子産物である。近年, YamamotoらはA 抗原を 決定するA 転移酵素をコードする相補的 DNA のクローニングとその塩基配列の決定に成功し,
それを手掛かりに $\mathrm{A} ， \mathrm{~B}$ および $\mathrm{O}(\mathrm{H})$ 転移酵素の 塩基置換を明らかにした ${ }^{344)}$. すなわち，A 転移酵 素と $\mathrm{B}$ 転移酵素の cDNA 間には 7 塩基置換と, 4 アミノ酸置換を認めた。この転移酵素が共通の 基質に型特異的な糖を転移することにより，A 型 抗原， $\mathrm{B}$ 型抗原は生成される。また， $\mathrm{O}$ 型遺伝子 は A 型遺伝子の一つの塩基欠失により, フレーム シフトが起こり，終止コドンが生じ，糖転移酵素 活性を持たなくなる。

な技，A，B転移酵素は，A，Bそれぞれの抗原 を発現する細胞から産生され，その産生細胞にの み作用するのか，あるいは細胞外に分泌され，他 の細胞にも及ぶのか，そのいずれであるかはまだ 明らかではない，今回，私達は赤血球系細胞に拉 
ける A，B転移酵素の産生扎よび A，B各抗原の 発現メカニズムについて，Wada ら5)の開発した 赤血球前駆細胞に対する選択的液体培養法を用い て検討をおこなったので報告する。

\section{材料および方法}

\section{1. 血液}

$\mathrm{A}, \mathrm{B}, \mathrm{O}$ 型の健常人ょりヘパリン存在下で末梢 血液を採血し遠心比重法により単核細胞を分離 し，実験に用いた。

\section{2. 選択的液体培養法}

選択的培養法は Wada 5 5の方法に従い二段階 法で括こなった。培養第 1 相では，末梢血液より 遠心比重法で分離した単核細胞をIscove's modified Dulbecco's medium (以下 IMDM) （Gibco，米国）を用いて，2度洗浄した後， $5 \%$ phytohemagglutinin-stimulated leukocyte conditioned medium(以下 PHA-LCM)，10\%ウシ胎 児血清（以下 FCS）（Flow Laboratorie，オース トラリア)を含むIMDM に浮遊させた。細胞数は $1 \times 10^{6} / \mathrm{m} l$ に調整し, $25 \mathrm{~cm}^{2}$ の組織培養フラスコ (Corning, 米国)を用いて，5\% $\mathrm{CO}_{2} ， 37^{\circ} \mathrm{C}$ の条件 下で 5 日間培養した。 な抏, PHA-LCM は, Suda $ら^{6)}$ の方法に従い末梢血より得られた単核細胞 $\left(2 \times 10^{6} / \mathrm{m} l\right)$ を $1 \% \mathrm{PHA}$ と $10 \% \mathrm{FCS}$ 含む IMDM に浮遊させ, $5 \% \mathrm{CO}_{2}, 37^{\circ} \mathrm{C}$ の条件下で 7 日 間培養して得られた上清を用いた。培養第 1 相終 了後, 培養細胞中の貪食細胞は Tebbi らの方法 に従いカルボニル鉄を用いて除去した。

培養第 2 相では，培養細胞中の非貪食細胞を $30 \%$ ウ胎児血清， $1 \%$ ウシ血清アルブミン (Sigma，米国）そして $2 \mathrm{U} / \mathrm{m} l$ エリスロポエチン (Epo，雪印乳業，日本）を含むIMDM に浮遊させ てその細胞数を $1 \times 10^{6} / \mathrm{m} l$ とし $, 5 \% \mathrm{CO}_{2}, 5 \% \mathrm{O}_{2}$, $37^{\circ} \mathrm{C}$ の条件下で再培養した。なお，ここでは $\mathrm{A}$, $\mathrm{B}, \mathrm{O}$ 各血液型細胞の単独括よび混合培養を打こ なった。第 2 相で得られた培養細胞は，各培養系 においてその経過を追うため，サイトスピンで塗 抹標本を作成して検鏡した。

\section{3. フローサイトメトリー法}

$\mathrm{A}$ および $\mathrm{B}$ 抗原の解析は橋本ら ${ }^{8)}$ の方法に従 い, モノクローナル抗 $\mathrm{A}$, 抗 $\mathrm{B}$ 打よび抗 $\mathrm{A}+\mathrm{B}$ 抗
体を用い，器材は Ortho（米国）製 Spectrum III を使用した。解析用試料の調製は，まず，約 $1 \times$ $10^{6}$ 個の赤血球および培養細胞を $\mathrm{pH} 7.3 ， 0.06 \mathrm{M}$ PBS で 2 回洗浄した後, PBS で $0.3 \%$ 細胞浮遊液 とした。 その細胞浮遊液に当教室で作製したモノ クローナル抗 $\mathrm{A}$, 抗 $\mathrm{B}$ 打よび抗 $\mathrm{A}+\mathrm{B}$ 抗体を 100 $\mu l$ ずつを混合し, $37^{\circ} \mathrm{C} て ゙ 30$ 分間感作した。.その後, FITCで標識した抗マウス免疫グロブリン抗体で 再度感作し, PBS で 2 回洗浄した後, Spectrum IIIによって解析を試みた。なお, 単核細胞の観察 時には，サイトグラム上でリンパ球分画と単核球 分画にそれぞれ枠組みし，陽性細胞数を分析した。

4. A および B 転移酵素活性の測定

ガルサーブ AB（住友精化, 日本）および RIA 法を用いて培養上清中の $\mathrm{A}$ 扣よび $\mathrm{B}$ 転移酵素活

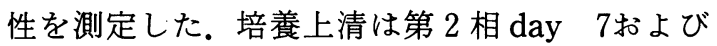
day 11のものを使用した。

ガルサーブ ABでは，培養上清をUDP-Ga1 NAc またはUDP-Gal の存在下で $\mathrm{O}$ 型血球と反 応させ，上清中に含有される $\mathrm{A}$ または $\mathrm{B}$ 転移酵 素を作用させた後で抗 $\mathrm{A}$, 抗 B 血清に対する被凝 集価を求め, これを $\mathrm{A}, \mathrm{B}$ 転移酵素の力価とした。

RIA 法では，培養上法を UDP-GalNAc または UDP-Gal の存在下で $\mathrm{O}$ 型血球と反応させ，マウ

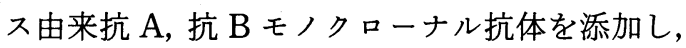
さらに ${ }^{125} \mathrm{I}$ 標識抗マウス IgG 抗体を反応させた。 その後, 感作血球を洗浄し, ガンマカウンターを 用いて測定した。

\section{結果}

選択的液体培養法による培養第 2 相 day 0 およ び day 9に扣ける培養細胞像を Fig. 1 に示す. day 0ではほとんどが芽球である。しかし，day 9 に扣いては多数の正染性赤芽球に加京赤血球も認 められた。

培養第 2 相 day 0から day 9の各培養日におけ る培養細胞の形態学的変化を Fig. 2 に示す.すな わち, 培養第 2 相 day 0に扣いては, 芽球が $99.9 \%$ を占め， day 1には前赤芽球と好塩基性赤芽球， day 4には多染性赤芽球, day 5 には正染性赤芽球, そして day 6には赤血球の出現を認めた。

培養第 2 相に扮ける $\mathrm{A}, \mathrm{B}$ 各抗原の発現状態は 

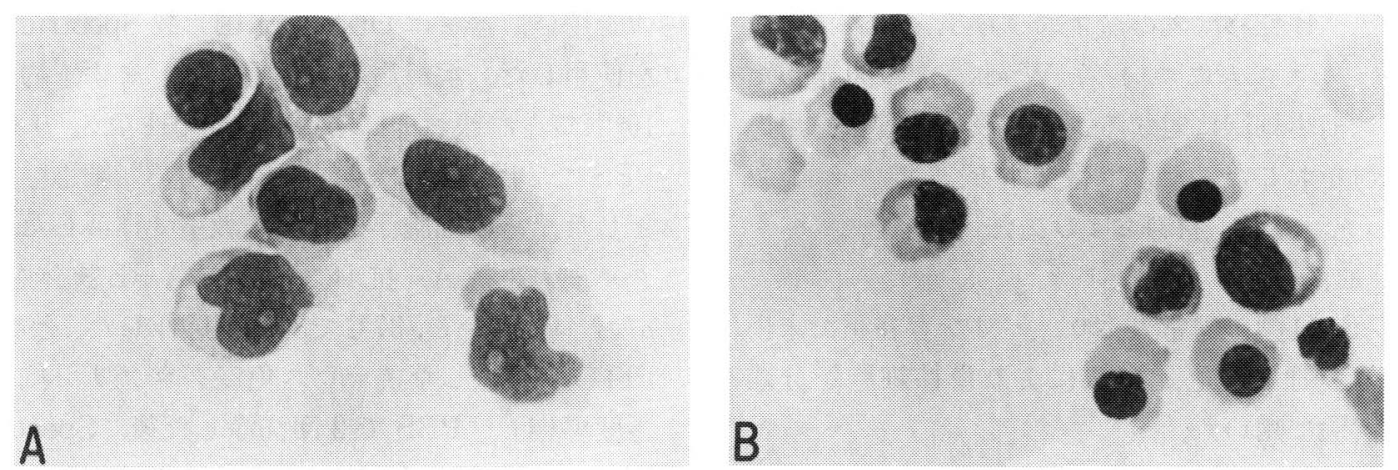

Fig. 1 Morphological changes on cultured cells during the second phase of the culture. (A) at day 0 ; and (B) at day 9.

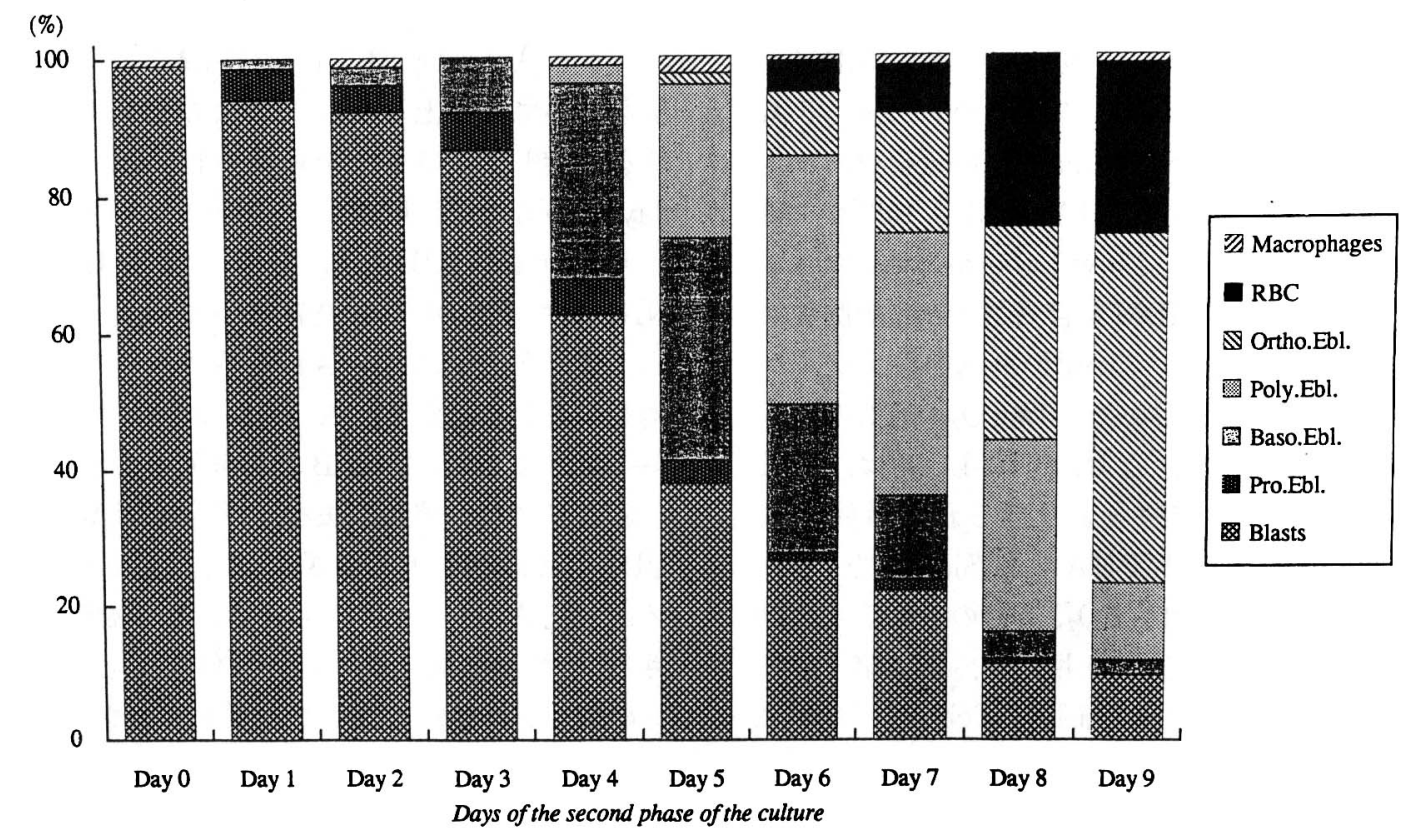

Fig. 2 Morphological profile of cultured cells during the second phase.

Fig. 3 に示す。すなわち A, B 各抗原は day 2 に 若干出現し始め, day 4には急激な増加を示した。 そして day 6には核ぼプラトーに達した。

$\mathrm{A}, \mathrm{B}, \mathrm{O}$ 型健常人由来の赤血球前駆細胞を $\mathrm{A}$ 型 $+\mathrm{O}$ 型, $\mathrm{B}$ 型 $+\mathrm{O}$ 型, $\mathrm{A}$ 型 $+\mathrm{B}$ 型の組又合わせ で混合培養し，培養第 2 相 day 11に打ける正染性 赤芽球および赤血球の出現率を観察したところ, いずれの組み合わせにおいてもその出現率は $80 \%$ であり, 各混合培養間における分化, 成熟には特 に差異は認められなかった。
フローサイトメトリー法による解析の結果は Table 1 に示すように, $\mathrm{A}$ 型 $+\mathrm{O}$ 型混合培養では 抗 A $21.3 \%$, 抗 B 1.1\%, 抗 A+B 25.9\%, B 型+ O 型混合培養では抗 A $1.7 \%$, 抗 B $14.2 \%$, 抗 A + B 19.4\%の陽性率を示し, O 型細胞には A お よび B 抗原は認められなかった. $\mathrm{A}$ 型 $+\mathrm{B}$ 型混合 培養では抗 A $18.5 \%$, 抗 B $15.1 \%$, 抗 A+B $37.6 \%$ であり, A, B 抗原陽性率に著しい差は認め られなかった。

ガルサーブ AB および RIA 法を用いた培養上 


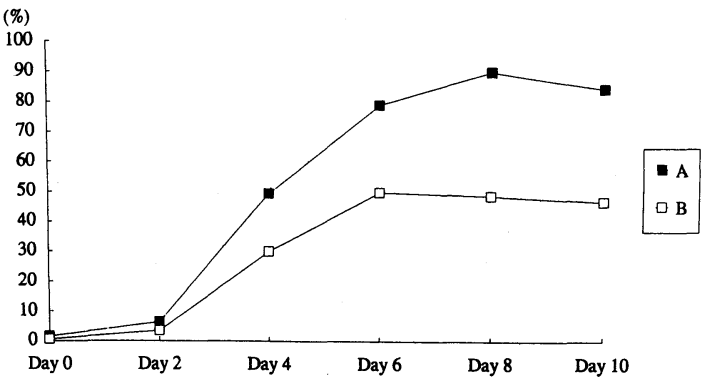

Fig. 3 Expression of the $\mathrm{A}$ and $\mathrm{B}$ antigens on cultured cells in the second phase detected by flow cytometric analyses using monoclonal anti$\mathrm{A}$ and anti-B antibodies.

清中の $\mathrm{A}$ 抢よび $\mathrm{B}$ 転移酵素活性の測定結果は, $\mathrm{A}$ および B 転移酵素活性はいずれも検出されな かった。

\section{考察}

血液型物質に関する生化学的研究によると A 扣よび B 抗原は $\mathrm{O}$ 抗原物質を前駆体として合成 されると説明されている。しかし，これを血球細 胞分化の過程で実験的に説明した報告はない。そ

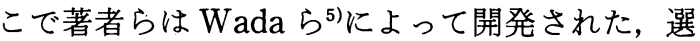
択的培養法を応用し, $\mathrm{O}$ 型血球由来培養細胞の $\mathrm{A}$ および B 型への転換を検討してみた。すすなわ， $\mathrm{A}, \mathrm{B}$ 抢よび $\mathrm{O}$ 型赤血球前駆細胞を $\mathrm{A}$ 型 $+\mathrm{O}$ 型, $\mathrm{B}$ 型 $+\mathrm{O}$ 型, $\mathrm{A}$ 型 $+\mathrm{B}$ 型の組み合わせで混合培養 し，フローサイトメトリー法により抗 $\mathrm{A}$, 抗 $\mathrm{B}$, 抗 $\mathrm{A}+\mathrm{B}$ モノクローナル抗体を用いて $\mathrm{A}$ 抗原招 よび $\mathrm{B}$ 抗原の発現を試みた。しかし， $\mathrm{O}$ 型培養細 胞の $\mathrm{A}, \mathrm{B}$ 型への転換, $\mathrm{A}$ 型培養細胞の $\mathrm{B}$ 型への 転換, $\mathrm{B}$ 型培養細胞の $\mathrm{A}$ 型への転換などは惹起さ れなかった。

また, ガルサーブ AB および RIA 法を用いた培 養上清中に打ける糖転移酵素活性の検出も試みた が，A 招よび B 転移酵素活性は検出されなかった にもかかわらず，培養細胞には $\mathrm{A}$ および $\mathrm{B}$ 抗原 の発現は認められた。この事実は $\mathrm{A}$ 㧊よび $\mathrm{B}$ 転 移酵素は，A 型および $\mathrm{B}$ 型血球細胞自体に存在 し，当該細胞に拈ける型物質の産生に関与してい ることを示唆するものかも知れない.

同種骨髄移植においては，ABO システムは組 織適合抗原としては重要ではなく, ドナーとレシ
Table 1 Flow cytometric analyses of various cultured cells at day 11 of the second phase using monoclonal anti- $\mathrm{A},-\mathrm{B}$ and $-\mathrm{A}+\mathrm{B}$ antibodies

\begin{tabular}{c|r|c|c}
\hline \multirow{2}{*}{$\begin{array}{l}\text { Blood groups of } \\
\text { cultured cells }\end{array}$} & \multicolumn{3}{|c}{ Monoclonal antibodies } \\
\cline { 2 - 4 } & Anti-A & Anti-B & Anti-A+B \\
\hline A & 72.1 & 1.8 & 53.3 \\
B & 2.0 & 49.9 & 56.7 \\
O & 3.2 & 2.6 & 0.8 \\
\hline A + O & 21.3 & 1.1 & 25.9 \\
B + O & 1.7 & 14.2 & 19.4 \\
A + B & 18.5 & 15.1 & 37.6 \\
\hline
\end{tabular}

Values are percentage of $\mathrm{A}, \mathrm{B}$ or $\mathrm{A}+\mathrm{B}$ antigen-positive cells.

ピェントの $\mathrm{ABO}$ システムが不一致でも, 溶血性 輸血副作用を予防しながら移植をおこならことは 可能であると報告されている9，ABO システムの 不適合骨髄移植においては, レシピェントの赤血 球膜の $\mathrm{ABO}$ 型抗原は移植後15～57日よりドナー 型の赤血球抗原が検出されるようになり, やがて ドナー型に変わる。しかし, 血清中にはどの時期 に颃いてもドナー型の転移酵素活性は認められな いとする報告もある(10)11)。これは, 培養上清中には A-抢よび B-転移酵素活性を認めなかった今回の 実験結果とも合致する。

さらに, 本研究は $\mathrm{A}$ および $\mathrm{B}$ 転移酵素は cDNA クローニングより細胞膜外に活性部位（C 末端側）を有する膜貫通性蛋白であることを予測 した Yamamoto ら ${ }^{344)}$ の報告を裏付けるのではな かららか.

なお，赤血球前駆細胞に対する選択的液体培養 法は, 造血器官としての骨髄を介することなく， 成熟赤血球に至る血球分化を追うことも可能であ る. 最近 Kajii らは糖転移酵素を必要としない蛋 白性抗原である Rh システムについて，この系を 用いて赤血球の分化と抗原の発現拉よびその遺伝 子の分子生物学的解析を試み，新しい情報を得て (るる1213114)。こうした実験系の確立は血液型不適 合骨髄移植などにおける生着判定法の in vitroに おける実験系としても，その応用は期待できょう。

\section{結 語}

選択的液体培養法を用いて $\mathrm{A}, \mathrm{B}, \mathrm{O}$ 型各種赤血 
球前駆細胞の混合培養をおこなったところ，O 型 細胞には $\mathrm{A}$ および $\mathrm{B}$ 抗原は検出されず，同様に $\mathrm{A}$ 型細胞には $\mathrm{B}$ 抗原, $\mathrm{B}$ 型細胞には $\mathrm{A}$ 抗原は検 出されなかった。 また，培養上清中に $\mathrm{A} ， \mathrm{~B}$-転移 酵素活性は検出されなかった。な拉，O 型細胞の $\mathrm{A}, \mathrm{B}$ 型への転換, $\mathrm{A}$ 型細胞の $\mathrm{B}$ 型への転換, $\mathrm{B}$ 型 細胞の $\mathrm{A}$ 型への転換は䒩起されないと考えられ る.

謝辞 本稿を終えるにあたり，本研究の実施に際し貴重 なご意見を頂いた本学法医学・人類遺伝学教室の諸先生方 に深く感謝申し上げます。

本論文の要旨は第39回日本輸血学会総会 (京都) に括い て発表した。

\section{文献}

1）池本卯典, 富田 功：一赤血球の遺伝標識, 特に 亜型および変異型のリスト，日本医事新報，2694： 27-34, 1975.

2) Yamakawa, T.: Forty years of my study on erythrocyte glycolipids. Rinshoken 15 years of Research, p. 1-16, 1991.

3) Yamamoto, F., Marken, J., Tsuji, T., White, T., Clausen, H. and Hakomori, S.: Cloning and characterization of DNA complementary to human UDP.GalNAc: Fuc $\alpha 1 \rightarrow 2$ Gal $\alpha 1 \rightarrow$ 3GalNAc transferase (Histoblood group A transferase) mRNA. J. Biol. Chem., 265: 1146, 1990.

4) Yamamoto, F., Clausen, H., White, T., Marken, J. and Hakomori, S. : Molecular genetic basis of the histo-blood group ABO system. Nature, $345 ; 229-233,1990$.

5) Wada, H., Suda, T., Miura, Y., Kajii, E., Ikemoto, S. and Yawata, Y.: Expression of major blood group antigens on human erythroid cells in a two phase liquid cluture system. Blood, 75 ; 501-511, 1990.

6) Suda, T., Suda, J., Miura, Y., Hayashi, Y.,
Eguchi, M., Tadokoro, K. and Saito, M.: Clonal analysis of basophil differentiation in bone marrow culture from a Down's syndrome patient with megakaryoblastic leukemia. Blood, 66 : 1278, 1985.

7) Tebbi, K., Rubin, S., Cowman, D.H. and McCulloch, E.A.: A comparison of granulopoiesis in culture from blood and marrow cells of nonleukemic individuals and patients with acute leukemia. Blood, 48: 235, 1976.

8）橋本好一, 中木陽子, 雨宮洋一：フローサイトメ トリーによる赤血球膜抗原, 抗体の測定法。免疫 と血液, 8:457, 1986.

9）原田実根，中尾真二，上田幹夫，近藤邦夫，尾高 和亮, 大竹茂樹, 塩原信太郎, 末永孝生, 森 孝 夫, 吉田 喬, 服部絢一：ABO 不適合ドナーから の同種骨䯣移植. 臨床血液, $25: 45-51,1984$.

10）森 孝夫, 吉本良三, 安江静香, 湯上礼子, 原田 実根，松田 保：ABO 式血液型不適合同種骨髄 移植後の型転移酵素活性，血液凝集素価の推移. 医学のあゆみ, $133: 327,1985$.

11) Ikemoto, S., Kajii, E., Tsuchida, S., Amemiya, Y., Kato, K. and Miura, Y.: Behavior of genetic markers in recipients after bone marrow transplantation and problems in forensic medicine. J. Foren. Sci., 35 : 548-553, 1990.

12) Kajii, E. and Ikemoto, S. : A new method for isolation of $\mathrm{Rh}$ polypeptide mRNAs using a liquid culture system. Proc. Jap. Acad., 68 : 51 $-56,1992$.

13) Kajii, E., Umenishi, F. and Ikemoto, S.: A cDNA clone encoding a $\mathrm{Rh}$ polypeptide detected in RhD-negative erythroid cells. Vox Sang., $64: 196,1993$.

14) Kajii, E., Umenishi, F., Iwamoto, S. and Ikemoto, S.: Isolation of a new cDNA clone encoding an $\mathrm{Rh}$ polypeptide associated with the Rh blood group system. Hum Genet., 91 : 157 $-162,1993$. 